\title{
104 ストレスファイバー槽造の再樓築現象に必要なひずみ且の定量的評価
}

Quantitative evaluation of strain required for the stress-fiber reconstruction

○学 松尾 守 (神戸大·院) 正 佐藤 克也(神戸大·院)

正 安達泰治(神戸大·工) 正富田佳宏(神戸大·工)

Mamoru MATSUO

Grad. Sch. of Sci. \& Tech., Kobe University, Nada, Kobe

Katsuya SATO

Grad. Sch. of Sci. \& Tech., Kobe University, Nada, Kobe

Taiji ADACHI

Dept. Mech. Eng., Fac. Eng., Kobe University, Nada, Kobe

Yoshihiro TOMITA

Dept. Mech. Eng., Fac. Eng., Kobe University, Nada, Kobe

Key words: Cell Biomechanics, Mechanobiology, Cytoskeletal Stress Fiber Structure, Osteoblastic Cell

\section{1.はじめに}

骨芽細胞内のストレスファイバー構造は，力学環境の変化に 伴い，その構造が動的に再構築されることが知られている(1), (2). 著者らも，これまでに骨芽細胞に単軸圧縮変形を与えるこ とで, ストレスファイバー構造の再構築が開始され，同構造が 消失する様子を実験的に観察してきた(3). しかしながら，ストレ スファイバー構造の再構築を引き起こすひずみや力などの力 学量について定量的に検討した例は少ない(4).そこで, 本研 究では, ストレスファイバー構造の再構築開始に必要なひずみ 量を定量的に評価することを目的としている. 予め単軸方向に 伸張させた状態のシリコーン膜上に骨芽細胞様細胞を培養し， その後，シリコーン膜の引張りひずみを解放することで細胞に 対して圧縮ひずみを与えた. それに伴うストレスファイバー構造 の変化を観察し, ストレスファイバー構造の再構築開始に必要 なひずみ量について検討した。

\section{2. 实敄方法}

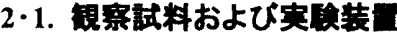

本実験では，骨芽細胞様細胞 MC3T3-E1 (理研 BRC より入 手)を用い，10\% FBS（SIGMA）を添加した $\alpha$-MEM（ICN） 培地を使用し，温度 $37^{\circ} \mathrm{C}$, 湿度 $100 \%, 5 \% \mathrm{CO}_{2}-95 \%$ Air の環

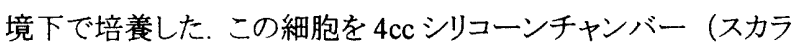
テック）に，細胞 $3.0 \times 10^{4}$ 個を播種し，同環境にて 24 時間培 養したものを実験に用いた

実験装置（Fig.1）は，2 本の並行なりニアガイド，及び，左 右両ネジシャフトに, 単軸 ( $\mathrm{x}$ 軸) 方向の平行移動が可能なスラ イダーを 2 つ取り付けたものである. シリコーンチャンバーは, 4 本のネジを用いてスライダーに固定した. スライダーは，左右 両ネジシャフトにより駆動され，ステッピングモーターを制御す ることで，シリコーンチャンバーに任意の単軸のひずみを与え ることが可能である.

\section{2・2. 实囹の概要}

実験の概要について述べる. Fig.2(a)に示すように，予め単 軸の引張りひずみを与えた状態のシリコーン膜上に細胞を培 養する. この時のシリコーン膜の引張り方向長さを $l_{0}$ とする. 次 に, 時刻 $t=0$ で, シリコーン膜を長さ $l$ まで縮めることでひずみ を解放し，細胞に圧縮ひずみ $\varepsilon_{\mathrm{sub}}=\left(l-l_{0}\right) / l_{0}$ を与える. 本 実験では， $\varepsilon_{\text {sub }}=-0.25$, ひずみ速度は-0.045/sec とした. これ に伴い, Fig.2(b)に示すように, 細胞の形状が変化する.この 細胞形状の変化に伴い, 細胞内では力学状態の不均衡が生 じ，ストレスファイバー構造の再構築が開始されると考えられる.

ひずみを与えた後のストレスファイバー構造の観察は蛍光観 察により行った. $t=15 \mathrm{~min}$ の時点で, $5 \%$ Paraformaldehyde によ り細胞を固定した. その後, $0.1 \%$ TRITON-X により細胞膜の脱

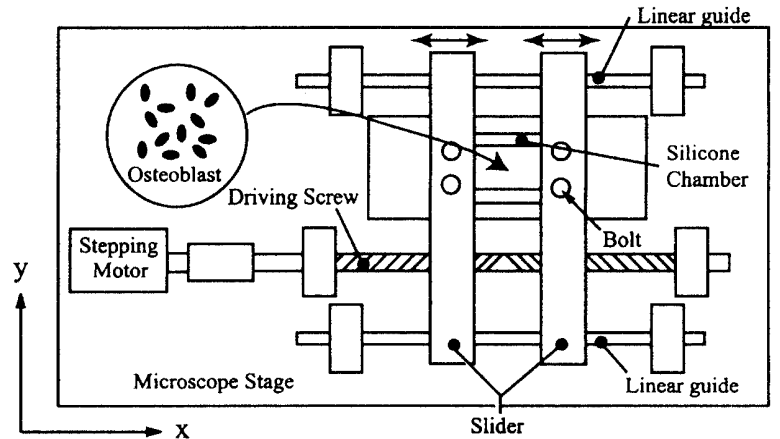

Fig.1: Experimental apparatus

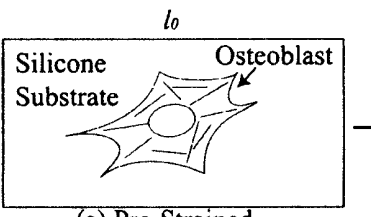

(a) Pre-Strained

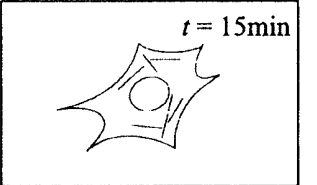

(c)Reconstruction

Fig.2 Definition of released strain ( $\varepsilon$ sub
膜処理を行い, Rhodamine-Phallodin によりストレスファイバーを 蛍光染色した．観察には，共焦点レーザ一走查型営光顕微鏡 (Nikon Degital Eclipse C1)を用いて, 細胞底面におけるストレ スファイバーの蛍光画像を取得し, $12 \mathrm{bit}$ の輝度データとして PC に記録した。

\section{3. 实硂拮果と考宗}

\section{3-1. 实溚结果}

Fig.3に, 細胞底面におけるストレスファイバー構造の蛍光画 像の例を示す．ひずみを与えていない通常細胞では Fig.3 (a) に示すように，細胞内全体に密なストレスファイバーの線維状 構造が観察される. 一方, Fig.3（b)に示す，ひずみを与えた細 胞では，細胞の輪郭付近にストレスファイバー構造が観察され るが, 細胞中央部ではストレスファイバーが消失しており, 通常 細胞で見られるような線維状構造は観察されない.このように， 単軸の圧縮ひずみを与えることにより, ストレスファイバー構造 が消失した細胞が観察された。しかしながら，全ての細胞にお いてこのようなストレスファイバー構造の消失が生じたわけでは なく, Fig.3 (c) に示すように, 通常細胞と同様のストレスファイバ 一構造を維持している細胞も観察された。

このように，同一の大きさの単軸圧縮ひずみを与えた場合で も，ストレスファイバー構造が消失した細胞と，消失しない細胞

日本機械学会〔No.03-38〕第16回バイオエンジニアリング講演会講演論文集('04.1.22〜23 北九州市) 


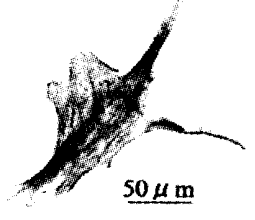

(a) control

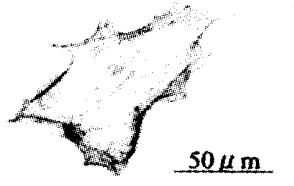

$\rightarrow$ Release direction

(b) Disappear

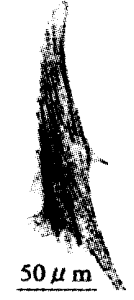

elease direction (c) Remain
Fig.3 Fluorescent images of stress fiber structure in osteoblastic cells

が観察された，骨芽細胞内では，ストレスファイバーは細胞形 状の長軸に平行した方向に配向している. したがって, 細胞に 対して単軸圧縮ひずみを与えた場合，ストレスファイバーの配 向方向に忍じて，同構造に与えられるひずみ量が変化する. そこで, ストレスファイバー自体に与えられるひずみ量が，再構 築の開始に重要な役割をすると考え, 両者の関係を検討した.

まず，Fig.4 (a)に示すように, 細胞輪郭形状の近似棈円を算 出し，その長軸方向と単軸圧樎方向とのなす角度を $\theta$ として定 義した. 次に， $\theta$ と単軸圧縮で与えた変形量を用いて，ストレ スファイバー自体に与えられるひずみ量 $(\varepsilon$ SF $)$ を, Fig.4(b)に 示す形で表現した. 本実験の場合では， $\theta$ と $\varepsilon$ SF は，Fig.4(c) に示すような関係になった。このようにして算出した \& SF を横軸 に, 細胞内ストレスファイバー構造の平均蛍光輝度を綐軸にプ ロット寸ると, Fig.5に示すグラフが得られた. 同グラフにおいて, $\left|\varepsilon_{\mathrm{SF}}\right|=0.00 \sim 0.05$ の細胞群に対して, $\left|\varepsilon_{\mathrm{SF}}\right|=0.05 \sim$ 0.20 の細胞群では, 平均輝度に有意な差は認められなかった。 一方, $\left|\varepsilon_{\mathrm{SF}}\right|=0.20 \sim 0.25$ の細胞群では, 蛍光輝度が有意 に低い結果が得られた $\left(p<1.0 \times 10^{-4}\right.$, T-test $)$.

\section{3-2. 考察}

細胞に対して，一様に $\varepsilon_{\text {sub }}=-0.25$ の圧縮ひずみを与えた 場合でも, ストレスファイバー構造が消失した細胞と, 消失して いない細胞が観察された.この結果から, ストレスファイバー構 造の再構築開始には，細胞に与えられるひずみ量ではなく, ストレスファイバー自体に与えられるひずみ量が重要であると 考えられる. また, ストレスファイバー構造自体に与えられるひ ずみ量 $\varepsilon$ SF と, ストレスファイバ一構造の平均蛍光輝度との関 係を検討した結果, $\mid \varepsilon$ SF $\mid<0.20$ の細胞群では, 蛍光輝度に 差異は認められなかったのに対して, $\left|\varepsilon_{\mathrm{SF}}\right|=0.20 \sim 0.25$ の 細胞群では，蛍光輝度が有意に低い結果が得られた。これら の結果から, ストレスファイバー構造の再構築開始に必要なひ ずみ量には閥値が存在し, その值は, 約-0.20 であることが示 唆される.

\section{4. おわりに}

本研究では，ストレスファイバー構造の再構築開始に必要な ひずみ量を定量的に評価することを目的として，シリコーン膜

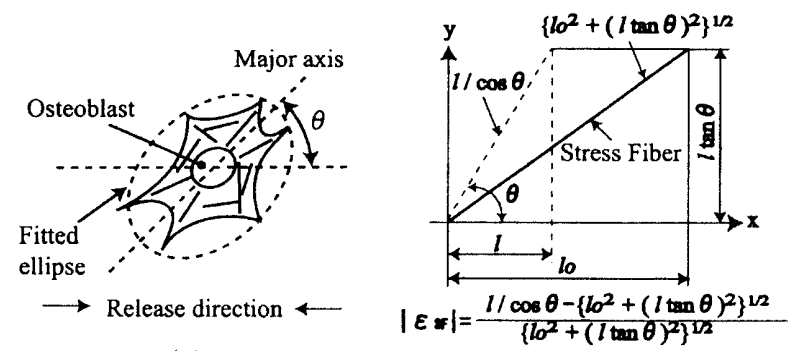

(a)

(b)

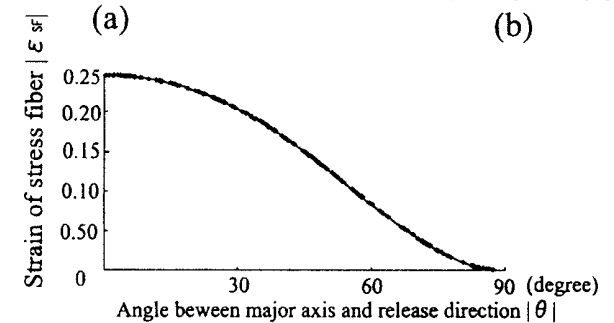

(c)

Fig.4 Relation between $\mid \varepsilon$ SF $\mid$ and $|\theta|$

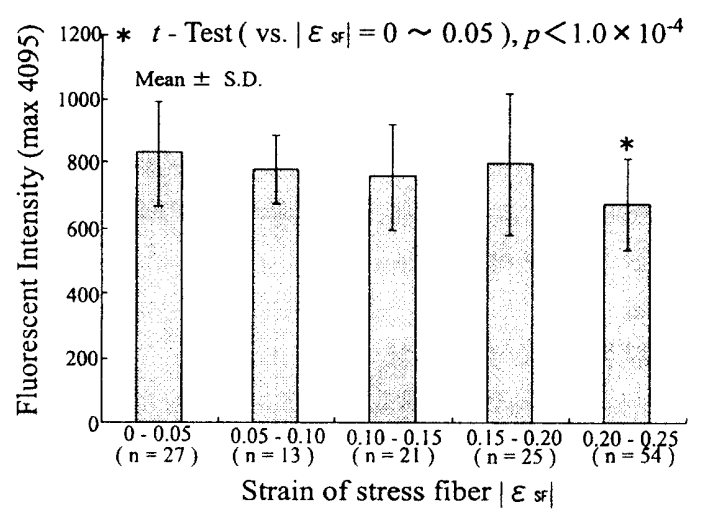

Fig. 5 Relation between strain of stress fiber $\left|\varepsilon_{\mathrm{SF}}\right|$ and fluorescent intensity

上に培養した細胞に単軸の圧縮ひずみを与え, 細胞内ストレ スファイバー構造の変化を観察した. その結果，ストレスファイ バーが消失するためには，細胞全体に対してではなく，ストレ スファイバー自体に与えられるひずみ量が重要であることおよ び，ストレスファイバー構造の再構築を開始させるひずみ量に 䦨值が存在し，その值は約-0.20 である可能性が示唆された.

\section{勒辞}

本研究は，一部文部科学省科学研究費補助金の援助のも とに行われた。ここに記して謝意を表する。

\section{考文献}

(1) Neidlinger-Wike, C., Grood, E. S., Wang. J. H. -C., Brand, R. A. and Claes, $\mathrm{L}$., Cell alignment is induced by cyclic changes in cell length: Studies of cell grown in cyclically stretched substrates, $J$. Orthop. Res., 19, (2001), 286-293.

(2) Chen, N. X., Ryder, K. D., Pavalko, F. M., Turner, C. H., Burr, D. B., Qiu, J. and Duncan, R. L., $\mathrm{Ca}^{2+}$ regulates fluid shear-induced cytoskeltal reorganization and gene expression in osteoblasts, $\mathrm{Am}$. J. Physiol. Cell Physiol. 278, (2000), C989-C997.

（3）松尾守，佐藤克也，安達泰治，富田佳宏., 細胞外基質のひず み解放に伴う細胞内アクチンファイバー構造変化の観察,第14回 バイオエンジニアリング部門講演会講演論文集, (2003), 5-6.

(4) Costa, K. D., Hucker, W. J. Yin, F. C. -P., Bucking of actin stress fibers: A new wrinkle in the cytoskeletal tapestry, Cell Mobility and the Cytoskeleton 52, (2002), 266-274. 